\title{
PENGEMBANGAN KAPASITAS GURU MELALUI PENGEMBANGAN \\ MEDIA PEMBELAJARAN INTERAKTIF BERBASIS TEKNOLOGI \\ INFORMASI DI MINU WARU SIDOARJO
}

\author{
Hanik Yuni Alfiyah, Asma' Naily Fauziyah, Masfufah \\ (Universitas Sunan Giri Surabaya)
}

\begin{abstract}
Abstrak:
Artikel ini merupakan hasil penelitian jenis ParticipatoryActionResearch (PAR) yang bertujuan untuk meningkatkan kapasitas guru di komunitas madrasah, yakni MINU Waru Sidoarjo dalam mengembangkan media pembelajaran berbasis teknologi informasi. Subjek penelitian terdiri dari 19 orang. Tahap-tahap penelitian meliputi perencanaan, tindakan, observasi, dan refleksi dalam empat siklus. Hasil penelitian menunjukkan bahwa kapastias guru MINU Waru Sidoarjo dalam mengembangkan media pembelajaran berbasis Teknologi Informasi meningkat melalui penerapan pelatihan pengembangan media pembelajaran interaktif berbasis $M s$. Power Point yang meliputi: 1) Pembuatan teks, tabel, grafik, flowchart, input gambar dan clipart; 2) Pembuatan animasi pada slide, gambar, smart art; 3) Desain media pembelajaran yang meliputi pembuatan template,content/isi, hyperlink, dan slide master, serta 4) Pembuatan presentasi efektif dengan Ms. Power Point.
\end{abstract}

Kata Kunci: Pengembangan Kapasitas Guru, Media Pembelajaran, Teknologi Informasi. 


\begin{abstract}
:
This article is a report of Participatory Action Research (PAR), which aims to improve teacher capacity at Madrasah Ibtidaiyah Nahdlatul Ulama (MINU), Waru, Sidoarjo in developing technology-based learning media. Subject of the study consists of 19 people. The stages of research include planning, action, observation, and reflection in four cycles. The results showed that teachers' capacity in developing media-based learning through the application of information technology increased through interactive learning media development of Ms. Power Point which includes the following activities: 1) creating text, tables, charts, flowcharts, input images and clipart; 2) Making an animation on a slide, picture, smart art; 3) Designing instructional media covering the manufacture of templates, content / content, hyperlinks, and slide master, as well as 4) Making an effective presentation by Ms. Power point.
\end{abstract}

\title{
Keywords: Teacher Capacity Building, Learning Media, Information Technology.
}

\section{A. Pendahuluan}

Proses belajar mengajar merupakan inti dari proses pendidikan secara keseluruhan dengan guru sebagai pemegang peran utama dalam menentukan keberhasilan proses pembelajaran. Guru sebagai tenaga edukatif mempunyai posisi strategis, karena mempunyai pengaruh langsung terhadap proses pembelajaran. Secara umum, guru menjadi tumpuan kemajuan kehidupan bangsa melalui proses sosialisasi dan internalisasi nilai-nilai. Oleh karenanya, kehadiran guru mutlak dibutuhkan dalam pembelajaran.

Persepsi tersebut menuntut guru untuk memiliki wawasan yang luas, cakap, kreatif, mandiri, berakhlak mulia serta menguasai ilmu pengetahuan dan teknologi. Dengan kata lain, guru harus memiliki keseimbangan dalam menguasai ilmu pengetahuan dan teknologi (IPTEK) dan kestabilan iman dan takwa (IMTAK). Guru juga memiliki andil yang besar bagi pengembangan ilmu pengetahuan dan teknologi, salah satunya yaitu dengan cara memanfaatkan kemajuan ilmu pengetahuan dan teknologi sebagai media pembelajaran.

Pemakaian media pembelajaran sangat membantu dalam kegiatan pembelajaran khususnya pada Sekolah Dasar sampai Sekolah Menengah. Dengan media pembelajaran, siswa dapat lebih mempunyai gambaran yang nyata tentang materi pembelajaran. Oleh karenanya, seorang guru harus mampu mempersiapkan media-media pembelajaran, baik dibuat dengan peralatan sebenarnya ataupun menggunakan teknologi informasi. 
Sebuah permasalahan yang ada jika menggunakan media pembelajaran dengan alat yang sebenarnya adalah harga yang sangat mahal. Oleh karenanya hal tersebut dapat diatasi dengan cara membuat sendiri media pembelajaran dengan memanfaatkan sumber daya yang dimiliki sekolah yaitu laboratorium komputer yang tersambung dengan jaringan internet. Sumber daya ini dapat digunakan sebagai pendukung untuk mengembangkan media pembelajaran yang lebih baik sehingga siswa dapat lebih mudah memahami materi yang disampaikan oleh guru.

Sebagai contoh materi pelajaran yang berkaitan dengan tata surya, dulu tata surya terdiri dari sembilan planet, akan tetapi sekarang telah berubah menjadi delapan planet karena ternyata Pluto bukanlah sebuah planet. ${ }^{1}$ Disinilah perlunya media pembelajaran yang memanfaatkan teknologi informasi untuk menjawab dan menjelaskan fenomena tersebut. Melalui Teknologi Informasi, jawaban dan penjelasan akan dapat lebih mudah dipahami oleh siswa, hal ini dikarenakan sifat multimedia yang melibatkan teks, suara, dan gambar.

Media pembelajaran berbasis teknologi informasi erat sekali kaitannya dengan konsep multimedia. Tay dan Thompson sebagaimana dinyatakan oleh Muhammad Anas mendefinisikan, multimedia sebagai kombinasi teks, grafik, suara, animasi dan video secara interaktif.Multimedia merupakan semua media yang berbeda karakteristiknya namun digunakan untuk tujuan yang sama, minimal mendukung pencapaian tujuan makna yang ingin dipahami oleh khalayak dari pihak komunikator. ${ }^{2}$

Suprapto, ${ }^{3}$ menyatakan bahwa manfaat dalam menggunakan media pembelajaran dengn teknologi informasi antara lain: 1) Dapat meningkatkan dan pengembangan keilmuan bagi guru dan siswa khususnya dalam berkreasi dan berinovasi, dan akibat inovasi tersebut dapat meningkatkan kreatifitas, keuletan serta kemampuan siswa; 2) Sebagai media untuk mendapatkan metode pembelajaran yang sesuai dengan keinginan siswa sehingga siswa dapat lebih menyukai pembelajaran; 3) Sebagai cara untuk mengatasi keterbatasan media pembelajaran yang belum tersedia di sekolah; 4) Sebagai cara untuk mengatasi kejenuhan siswa disekolah karena media pembelajaran yang monoton; 5) Dapat menghemat biaya pendidikan, walaupun pada saat pertama kali perlu biaya yang besar, tetapi untuk selanjutnya akan jauh lebih murah. Hal ini dikarenakan sifat teknologi adalah universal, sehingga dapat digunakan dalam berbagai fungsi

\footnotetext{
${ }^{1}$ www.wikipedia.com, diakses pada tanggal 11 Mei 2014.

2 Muhammad Anas, "Pemanfaatan TIK dalam Pembelajaran di ProvinsiSulawesi Utara,"Jurnal Simposium Pendidikan, Vol.4.2, 2009.

${ }^{3}$ Suprapto, "Peningkatan Kualitas Pendidikan MelaluiMedia Pembelajaran Menggunakan Teknologi Informasi di Sekolah,"Jurnal Ekonomi dan Pendidikan, Vol.3.1, 2006.
} 
yang berbeda; 6) Dengan adanya pengembangan kurikulum melalui inovasi media pembelajaran berbasis Teknologi Informasi di sekolah, diharapkan masyarakat dapat ikut menggunakan dan memanfaatkan media pembelajaran yang telah tersedia; 7) Memungkinkan adanya perubahan paradigma pendidikan yang lebih baik.

Beberapa manfaat tersebut di atas tidak hanya ditujukan kepada siswa yang mengikuti proses belajar mangajar, tetapi juga guru, siswa dan masyarakat luas pada umumnya. Dengan merebaknya teknologi ini, yang hampir setiap rumah khususnya dikota-kota sudah memilikinya, maka media pembelajaran ini juga sangat mungkin dipelajari dirumah. Hal ini dikarenakan media ini berupa perangkat lunak yang dapat di copy oleh para siswa khususnya yang belum dapat memahaminya ketika disekolah. ${ }^{4}$

Penelitian ini merupakan jenis penelitian tindakan (actionresearch) yang berusaha meningkatkan kapasitas guru madrasah, yakni MINU Waru Sidoarjo dalam mengembangkan media pembelajaran interaktif berbasis teknologi informasi.Sehingga rumusan masalah dalam penelitian ini adalah: "Bagaimana meningkatkan kapasitas guru MINU Waru Sidoarjo dalam mengembangkan media pembelajaran berbasis teknologi informasi?". Penelitian ini memberikan kontribusi berupa meningkatnya kapasitas guru MINU Waru Sidoarjo dalam mengembangkan media pembelajaran interaktif berbasis teknologi informasi.

\section{B. Kapasitas Guru MINU Waru Sebelum PAR}

Berdasarkan hasil interview yang telah dilakukan oleh tim peneliti, ${ }^{5}$ maka dapat diilustrasikan kondisi guru MINU Waru II Sidoarjo sebagai berikut: MINU Waru Sidoarjo memiliki jajaran guru dengan jumlah yang cukup, yaitu 19 orang. Dari hasil wawancara dengan key person di madrasah, jajaran guru terdiri dari dua jenis latar belakang pendidikan, yaitu guru dengan latar belakang pendidikan akademik kependidikan yang memiliki kompetensi dalam bidang pengajaran serta guru dengan latar belakang pendidikan yang tidak memiliki kompetensi dalam hal pengajaran.

Selama ini, guru banyak menggunakan media pembelajaran berupa spidol dan papan tulis saja ataupun alat peraga yang dibeli dengan harga yang tidak murah, padahal fasilitas computer, laptop dan LCD/proyektor telah tersedia di sekolah dan dapat dimanfaatkan secara bebas dalam proses pembelajaran. Hanya saja guru masih merasa kesulitan dalam menggunakan dan mengembangkannya sebagai media pembelajaran.

\footnotetext{
4 Suprapto, "Peningkatan Kualitas Pendidikan."

${ }^{5}$ Zawidah Abdullah (Kepala Sekolah), Wawancara pada tanggal 8 Januari 2015. 
Kesulitan yang dialami guru-guru di MINU Waru Sidoarjo dalam mengembangkan media pembelajaran berbasis teknologi informasi ini dilatarbelakangi oleh berbagai alasan, antara lain: kurangnya pengalaman guru dalam mempelajari/ berlatih mengembangkan media pembelajaran berbasis teknologi informasi, terbatasnya waktu untuk belajar dan berlatih secara mandiri dalam mengembangkan media pembelajaran berbasis teknologi informasi di luar jam sekolah, serta alokasi biaya yang sangat mahal untuk mendatangkan trainer dalam mengembangkan media pembelajaran berbasis teknologi informasi.

Berdasarkan hal tersebut di atas, maka perlu sebuah pendampingan untuk guru-guru MINU Waru Sidoarjo dalam mengembangkan kapasitasnya di bidang media pembelajaran berbasis teknologi informasi. Hal itu dimaksudkan agar pembelajaran yang diberikan oleh guru-guru MINU Waru Sidoarjo kepada murid-muridanya menjadi lebih menarik dan efektif.

\section{Harapan MINU Waru Setelah PAR}

Berdasarkan hasil interview dan diskusi informal yang telah dilakukan, ${ }^{6}$ dapat digambarkan kondisi yang diharapkan dari madrasah dampingan adalah sebagai berikut:

1. Guru terampil dalam mengembangkan media pembelajaran interaktif berbasis teknologi informasi

2. Penggunaan media pembelajaran yang variatif, tidak hanya terfokus pada spidol dan papan tulis dan alat peraga (sebagai salah satu dari bentuk media),

3. Guru dapat menghadirkan media pembelajaran yang berhubungan dengan materi yang membutuhkan waktu dan proses yang panjang (misal materi metamorfosis kupu-kupu) dalam waktu singkat.

4. Mengakomodir karakteristik (gaya belajar) siswa yang tidak sama.

Beberapa harapan di atas diupayakan tercapai melalui sebuah pendampingan di bidang media pembelajaran berbasis teknologi informasi dalam kurun waktu yang memungkinkan untuk membuat guru-guru yang didampingi mampu membuat media pembelajaran berbasis teknologi informasi agar pembelajarannya lebih menarik.

${ }^{6}$ Tiyuk Fu'adah (Guru Komputer), Wawancara pada tanggal 14 Januari 2015. 


\section{Strategi yang Dilakukan di MINU Waru}

Penelitian ini dilakukan dalam bentuk siklus, masing-masing siklus terdiri dari beberapa komponen, yaitu tahap perencanaan, pelaksanaan tindakan, observasi dan refleksi serta kesimpulan hasil. Prosedur penelitian tindakan yang diterapkan dalam penelitian ini adalah sebagaimana berikut:

\section{Tahap Perencanaan}

Kegiatan yang dilakukan pada tahap perencanaan adalah sebagai berikut:

a. Forum Group Discussion (FGD)

Kegiatan ini dilakukan untuk mengklarifikasi hasil temuan riset awal yaitu problema praktis yang dihadapi komunitas dampingan MINU Waru II Sidoarjo adalah terkait rendahnya kapasitas guru dalam mengembangkan media pembelajaran interaktif berbasis teknologi informasi.

b. Workshop Agenda Aksi

Kegiatan ini dilakukan untuk menetapkan alternatif upaya peningkatan kapasitas guru dalam mengembangkan media pembelajaran berbasis teknologi informasi yaitu memberikan pelatihan pengembangan media pembelajaran berbasis Ms. Power Point.

2. Pelaksanaan Tindakan

Pelaksanaan tindakan dilakukan dengan melaksanakan pelatihan pengembangan media pembelajaran berbasis Ms. Power Point. Pelaksanaan tindakan dilakukan dalam bentuk siklus, tiap siklus diberikan materi yang berbeda. Sebelum pelaksanaan tindakan diberikan lembar angket yang berfungsi untuk mengetahui kemampuan awal peserta terhadap materi yang akan diberikan.

3. Pengamatan/Observasi

Pengamatan dilakukan dengan menggunakan lembar observasi yang telah dibuat. Pengamatan dilakukan selama proses tindakan guna mengamati kemampuan peserta dalam menguasai materi yang telah diajarkan.

4. Refleksi

Kegiatan ini dilakukan untuk merefleksi/merenungkan tindakan yang telah dilakukan serta mendiskusikan hal-hal yang berkenaan dengan pelaksanaan pelatihan. Selain itu juga dilakukan analisis terhadap hasil angket pra tindakan dan hasil observasi proses tindakan. Hasil analisis berupa angkaangka dan masukan-masukan digunakan untuk perbaikan pelaksanaan tindakan pada siklus berikutnya.

5. Kriteria Keberhasilan Tindakan

Kriteria merupakan patokan untuk menentukan keberhasilan suatu kegiatan atau program. Suatu program dikatakan berhasil apabila mampu mencapai kriteria yang telah ditentukan dan gagal apabila tidak mampu 
melampaui kriteria yang telah ditentukan. Oleh karena itu setiap evaluasi terhadap suatu program membutuhkan suatu kriteria. Adapun kriteria yang digunakan dalam penelitian ini adalah kriteria relatif, yaitu dengan membandingkan hasil sebelum tindakan dengan sesudah tindakan.

Adapun kriteria dalam penelitian ini adalah sebagai berikut: Untuk memberikan makna terhadap keberhasilan setelah pelaksanaan tindakan digunakan kriteria, yaitu suatu hasil setelah tindakan dibandingkan dengan standar minimal yang telah ditentukan. Adapun standar minimal yang telah ditentukan adalah sekurang-kurangnya nilai rerata indikator kapasitas peserta dalam mengembangkan media pembelajaran berbasis Ms. Power Point berada pada kategori tinggi. Apabila hasil tindakan sesuai dengan standar minimal yang telah ditentukan, maka tindakan dinyatakan berhasil. Ketika tindakan sudah dinyatakan berhasil, maka proses siklus penelitian dihentikan. Kemudian datadata yang ada diolah menjadi sebuah laporan yang utuh.

\section{E. Metode Penelitian}

Penelitian ini merupakan Participatory Action Researc (PAR). Pemilihan metode PAR didasarkan atas dasar masalah dan tujuan penelitian yang menuntut adanya penyempurnaan (tindak lanjut) berdasarkan prinsip daur ulang secara reflektif, kolaboratif, dan partisipatif yang dipusatkan pada situasi sosial dampingan. PAR merupakan bentuk penelitian sosial yang dilakukan oleh para peneliti professional yang berkolaborasi dengan sebuah kelompok organisasi yang bertujuan untuk mengkaji dan melakukan perubahan terhadap kelompok tersebut melalui proses pembelajaran yang terencana. Sebagaimana yang diungkapkan Grenwood:

"Participatory action research is a form of action research in which professional social researchers operate as full collaborators with members of organizations in studying and transforming those organizations. It is an ongoing organizational learning process, a research approach that emphasizes co-learning, participation and organizational transformation." 7

Sementara itu Green mendefinisikan PAR sebagai penelitian sistematis, yang dilakukan dalam bentuk kolaborasi (bekerjasama) dalam mengkaji sebuah isu (masalah yang dihadapi oleh komunitas yang diteliti), yang bertujuan untuk memberikan pendidikan dan melakukan perubahan. Sebagaimana yang dikatakannya sebagai berikut:

\footnotetext{
7 Greenwood, D. J., Whyte, W. F., \& Harkavy, I., "Participatory Action Research as a Process and as a Goal,"Human Relations, 46 (2), (1993): 175.
} 
"Participatory research is defined as systematic inquiry, with the collaboration of those affected by the issue being studied, for purposes of education and taking action or effecting change." 8

Reason and Bradbury menyatakan PAR sebagai sebuah pendekatan penelitian yang menekankan partisipasi dan tindakan pada masyarakat yang bertujuan untuk memahami dan melakukan perubahan secara kolaboratif dan reflektif. Sebagaimana dikatakannya sebagai berikut:

"Participatory action research (PAR) is an approach to research in communities that emphasizes participation and action. It seeks to understand the world by trying to change it, collaboratively and following reflection. PAR emphasizes collective inquiry and experimentation grounded in experience and social history. Within a $P A R$ process, "communities of inquiry and action evolve and address questions and issues that are significant for those who participate as coresearchers" 9

Bertolak pada beberapa argumen di atas, dapat disimpulkan bahwa PAR merupakan penelitian yang tidak hanya menggali data, tetapi juga melakukan transformasi sosial yang lebih baik berupa tindakan pemberdayaan terhadap komunitas yang diteliti. Ini berarti bahwa PAR bukanlah badan monolitik ide dan metode ansich melainkan orientasi pluralistik pengetahuan untuk membuat perubahan sosial.PAR kontras dengan banyak metode penelitian, yang menekankan peneliti tertarik pada reproduktifitas temuan pengetahuan saja.

Chevalier dan Buckles merumuskan pengintegrasian tiga aspek yang dilakukan oleh peneliti atau praktisi PAR dalam proses penelitian. ${ }^{10}$ Tiga aspek tersebut adalah: 1) Participatory, yaitu memberikan ruang partisipasi dalam kehidupan komunitas/kelompok yang didampingi; 2) Action, yaitu terlibat dalam tindakan nyata yang dilakukan; dan 3) Research, yaitu adanya peneliti dengan bekal pengetahuan untuk perencanaan awal yang kemudian dikolaborasikan dengan perencanaan hasil diskusi dengan komunitas yang diteliti.

\footnotetext{
${ }^{8}$ Green, et.al, "Appendix C: Guidelines for Participatory Research in Health Promotion," in Minkler, Meredith and Nina Wallerstein, ed. Community-Based Participatory Research for Health (San Francisco, CA: Jossey-Bass Inc.), 2003.

9 Reason, P. and Bradbury, H., 'Introduction', in P. Reason and H. Bradbury, ed.The Sage Handbook of Action Research: Participative Inquiry and Practice (CA: Sage, 2008), 5.

${ }^{10}$ Chevalier, J.M. and Buckles, D.J., Participatory Action Research: Theory and Methods for Engaged Inquiry(London: Routledge, 2013) , 10.
} 
Pengumpulan data dalam penelitian ini dilakukan dengan menggunakan beberapa teknik sebagai berikut:

1. Forum Group Discussion (FGD)

Teknik ini digunakan untuk mengumpulkan data awal tentang permasalahan yang dihadapi komunitas dampingan yang berhubungan dengan pengembangan media pembelajaran berbasis Ms. Power Point.

2. Wawancara

Teknik ini digunakan untuk menjaring data yang berkaitan dengan kapasitas awal komunitas dampingan dalam mengembangkan media pembelajaran berbasis Ms. Power Point, serta pendapat/responnya tentang pelaksanaan pelatihan pengembangan media pembelajaran berbasis Ms. Power Point.

3. Angket

Teknik ini digunakan untuk menjaring data mengenai kemampuan awal komunitas dampingan pada setiap siklus.

4. Observasi

Teknik ini digunakan untuk mengumpulkan data mengenai kapasitas guru dalam mengembangkan media pembelajaran berbasis Ms. Power Point yang dilakukan selama pelaksanaan tindakan.

5. Field notes/Catatan lapangan

Teknik ini digunakan untuk menjaring data mengenai kondisi lapangan selama proses pelatihan berlangsung.

Dalam penelitian ini terdapat dua metode analisis yang digunakan, yaitu metode analisis deskriptif kuantitatif dan metode analisis deskriptif kualitatif. Analisis data kualitatif dalam penelitian ini dilakukan dengan cara merefleksi hasil observasi terhadap proses pelatihan. Data yang berupa kata-kata atau kalimat dari catatan lapangan diolah menjadi kalimat-kalimat yang bermakna dan dianalisis secara kualitatif. Teknik ini mengacu pada model analisis dari Miles dan Huberman ${ }^{11}$ yang dilakukan dalam tiga komponen berurutan, yaitu: reduksi data, penyajian data, dan penarikan kesimpulan.

Dalam penelitian ini, reduksi data meliputi penyeleksian data melalui ringkasan atau uraian singkat, dan pengelolaan data ke dalam pola yang lebih terarah. Penyajian data dilakukan dalam rangka mengorganisasikan data yang merupakan penyusunan informasi secara sistematik dari hasil reduksi data mulai dari perencanaan, pelaksanaan tindakan, observasi, dan refleksi pada masing-masing siklus.Penarikan kesimpulan merupakan upaya pencarian makna data, mencatat keteraturan dan penggolongan data. Data yang terkumpul disajikan secara sistematis dan perlu diberi makna.

11 Miles, B.M. \& Huberman, D., Effective Teaching: Evidence \& Practice, $2^{\text {nd }}$ (London: Sage Publication, 1984), 21. 
Analisisdata yang berupa angka-angka mengenai kapasitas guru dalam mengembangkan media pembelajaran berbasis Ms. Power Point pada saat sebelum pelaksanaan tindakan dan selama pelaksanaan tindakan berlangsung dilakukan secara kuantitatif dengan menggunakan rentang interval yang diadaptasi dari Djemari Mardapi ${ }^{12}$ dengan 4 skala sebagaimana pada tabel 1.

Tabel 1. Kategori Penilaian Kapasitas Guru dalam Mengembangkan Media

Pembelajaran Berbasis Ms. Power Point

\begin{tabular}{|c|c|}
\hline $01,00-01,75$ & Sangat rendah \\
\hline $01,76-02,50$ & Rendah \\
\hline $02,51-03,25$ & Tinggi \\
\hline $03,26-04,00$ & Sangat tinggi \\
\hline
\end{tabular}

\section{F. Peningkatan Kapasitas Guru MINU Waru Melalui Ms. Power Point}

Pengembangan media pembelajaran berbasis teknologi informasi merupakan hal yang sangat menarik untuk dibahas. UNESCO mengklasifikasikan tahap penggunaan media pembelajaran berbasis teknologi informasi dalam pembelajaran ke dalam empat tahap, yaitu: a) Tahap emerging, baru menyadari pentingnya teknologi informasi untuk pembelajaran dan belum berupaya untuk menerapkannya, b) Tahap applying,menjadikan teknologi informasi sebagai obyek untuk dipelajari (mata pelajaran), c) Tahap integrating, teknologi informasi telah diintegrasikan ke dalam kurikulum (pembelajaran), d) Tahap transforming merupakan tahap yang paling ideal dimana teknologi informasi telah menjadi katalis bagi perubahan/evolusi pendidikan. Teknologi informasi diaplikasikan secara penuh baik untuk proses pembelajaran (instructional purpose) maupun untuk administrasi (administrational purpose).

Kondisi guru MINU Waru Sidoarjo berada pada tahapan applying yaitu menyadari pentingnya teknologi informasi untuk pembelajaran dengan menjadikannya sebagai obyek untuk dipelajari yaitu sebagai mata pelajaran TIK yang berfungsi untuk memperkenalkan peserta didik terhadap bentuk fisik teknologi informasi yaitu komputer, dan mengajarkan peserta didik untuk menggunakannya dalam satu mata pelajaran tersebut. Hal tersebut paradoks dengan apa yang dikatakan Fryer, ${ }^{13}$ bahwa penggunaan teknologi informasi dalam pembelajaran bertujuan untuk melatih keterampilan peserta didik dalam

\footnotetext{
12 Djemari Mardapi, Teknik penyusunan Instrumen Tes dan Non Tes (Yogyakarta: Rosda, 2008), 123.

${ }^{13}$ Fryer, Wesley A, "Strategy for effective Elementary Technology Integration", dalamhttp://www.wtvi.com/teks/integrate/tcea2001/ powerpointoutline, diakses pada 05 Januari 2015.
} 
menggunakan teknologi informasi dengan cara mengintegrasikannya ke dalam aktifitas pembelajaran, bukan mengajarkannya sebagai mata pelajaran yang terpisah.

Pengintegrasian teknologi informasi kedalam aktifitas belajar berarti pemanfaatan teknologi informasi oleh siswa (dalam penelitian ini berupa komputer) sebagai media pembelajaran pada setiap mata pelajaran. Aktifitas belajar tersebut sebagaimana dicontohkan oleh Arief AM dapat berupa kegiatan membuat teka teki Matematika atau soal bercerita dan diupload untuk mengajak teman-teman mencari jawabannya pada mata pelajaran matematika,membuat grafik yang menunjukkan macam-macam hobi teman sekelas pada mata pelajaran Bahasa Indonesia, membuat presentasi Ms. Power Point hasil diskusi pada mata pelajaran PKN, mencari sumber informasi dari internet, mengevaluasi, mengolah, dan mempublikasikannya pada mata pelajaran IPS, dan sebagainya. ${ }^{14}$

Pemanfaatan (pengintegrasian) teknologi informasi sebagai media pembelajaran oleh siswa sebagaimana dirumuskan oleh UNESCO sebagai tahap integrating, tentu menuntut keterampilan dan kemahiran seorang guru dalam mengaplikasikan teknologi informasi. Namun pada kenyataannya, kapasitas guru MINU Waru dalam mengaplikasikan teknologi informasi masih tergolong rendah. Berdasarkan hasil wawancara yang dilakukan, 85\% guru MINU Waru Sidoarjo masih belum memanfaatkan teknologi informasi sebagai media pembelajaran.

Rendahnya kapasitas guru dalam mengaplikasikan teknologi informasi dikarenakan sebagian besar guru MINU Waru Sidoarjo belum pernah memiliki pengalaman belajar membuat media pembelajaran interaktif berbasis teknologi informasi baik melalui lembaga kursus maupun otodidak. Dan sebagian kecil guru yang lain telah memiliki pengalaman belajar membuat media pembelajaran interaktif berbasis teknologi informasi namun belum mampu mengaplikasikannya dengan baik.

Rendahnya kapasitas guru dalam mengaplikasikan media pembelajaran berbasis teknologi informasi sangat kontra produktif dengan manfaat yang dimiliki media pembelajaran berbasis teknologi informasi sebagaimana dirumuskan oleh Arief Sadiman, antara lain: 1) menjadikankonsep yang abstrak menjadi lebih konkret, 2) mengatasi kendala keterbatasan ruang dan waktu, 3) membantu mengatasi keterbatasan indera manusia, 4) menyajikan objek

\footnotetext{
${ }^{14}$ Arief am, http://abiavisha.blogspot.com/2014/03/bahan-ajarku-media-pembelajaran.html diakses pada 5 Januari 2015.
} 
pelajaran berupa benda atau peristiwa langka dan berbahaya ke dalam kelas, 5) memungkinkan siswa mampu berinteraksi dengan lingkungan. ${ }^{15}$

Besarnya manfaat pengaplikasian media pembelajaran berbasis teknologi informasi sebagaimana yang telah dirumuskan tersebut, juga dipahami oleh guru MINU Waru II Sidoarjoyang menyatakan bahwa sosok seorang guru harus memiliki kemampuan dalam mengembangkan media pembelajaran interaktif berbasis teknologi informasi, karena hal tersebut dapat mempermudah penyampaian materi sehingga proses pembelajaran menjadi variatif, efektif dan efisien, serta materi pelajaran dapat lebih mudah dipahami oleh siswa. Selain itu, para guru juga beranggapan bahwa hal tersebut dapat meningkatkan kapasitas guru serta menjadikan guru peka terhadap perkembangan teknologi dan perubahan zaman. ${ }^{16}$

Kesadaran terhadap kekurangan diri serta keinginan untuk memperbaiki yang dialami oleh guru MINU Waru Sidoarjo sangat relevan dengan prinsip pengembangan kapasitas yang diungkapkan oleh Milen yaitu komitmen bersama (Collective commitments), ${ }^{17}$ aspek terpenting dari komitmen bersama (Collective commitments) adalah melibatkan komunitas itu sendiri. Proses pengembangan kapasitas harus menjadi sebuah proses yang dimiliki, dikuasai dan dilangsungkan oleh komunitas dampingan, karena mereka sendirilah yang mengerti akan kebutuhan, potensi, dan sumber daya yang dimiliki. Dalam pengembangan kapasitas tidak dibenarkan memandang komunitas dampingan sebagai sebuah gelas kosong. Komunitas dampingan, baik sebagai perorangan maupun sebagai kelompok, memiliki pengalaman hidup yang dapat menjadi sebuah sumber yang kaya bagi proses pembelajaran, sehinggamemiliki kemampuan untuk menetapkan tujuan-tujuannya sendiri. Hal tersebut juga relevan dengan yang diungkapkan oleh Suyanto, bahwa problema yang diangkat untuk dipecahkan dalam pengembangan kapasitas harus selalu berangkat dari persoalan-persoalan yang dihadapi komunitas dampingan. Jadi, pendampingan dapat dilaksanakan jika komunitas dampingan mmang mnyadari adanya persoalan yang dihadapi dan menganggap penting untuk memecahkan masalah tersebut. ${ }^{18}$

\footnotetext{
${ }^{15}$ Arief Sadiman, dkk., MediaPendidikan(Jakarta: Pustekkom Diknas \& PT. Raja Grafindo Perkasa), 16-17.

16 Wawancara terbuka dalam FGD dengan semua guru MINU Waru II Sidoarjo pada tanggal 8 januari 2015

17 Milen, Anelli, Pegangan Dasar Pengembangan Kapasitas, Terjemahan (Yogyakarta: Pondok Pustaka Jogja, 2004).

${ }^{18}$ Suyanto, Pedoman Pelaksanaan Penelitian Tindakan Kelas (PTK) (Yogyakarta: DIKBUD, 1997)
} 
Pengembangan kapasitas merupakan sebuah proses yang dilakukan untuk meningkatkan kemampuan individu, kelompok, organisasi, komunitas atau masyarakat untuk menganalisa lingkungannya; mengidentifikasi masalahmasalah, kebutuhan-kebutuhan, isu-isu dan peluang-peluang; memformulasi strategi-strategi untuk mengatasi masalah-masalah, isu-isu dan kebutuhankebutuhan tersebut, dan memanfaatkan peluang yang relevan; merancang sebuah rencana aksi, serta mengumpulkan dan menggunakan secara efektif, dan atas dasar sumber daya yang berkesinambungan untuk mengimplementasikan, memonitor, dan mengevaluasi rencana aksi tersebut, serta memanfaatkan umpan balik sebagai pelajaran. ${ }^{19}$

Terdapat tiga tingkatan ruang lingkup dalam pengembangan kapasitas, antara lain: tingkatan sistem, tingkatan organisasi, dan tingkatan individu. Peningkatan kapasitas dalam tataran sistem meliputi usaha yang bersifat luas dan banyak menekankan keterlibatan pemerintah dan pemegang kekuasaan lainnya terutama dalam mengembangkan sebuah sistem pembangunan yang berpihak kepada masyarakat. Dalam lingkup komunitas, proses peningkatan kapasitas adalah pada tataran kelembagaan komunitas dan pada tataran individu masyarakat.

Peningkatan kapasitas organisasi berarti usaha untuk meningkatkan peran dan mengembangkan tata kelembagaan di tingkat masyarakat yang mampu mewadahi setiap gagasan, usulan dan aspirasi dari masyarakat untuk kemajuan dalam komunitasnya. Peningkatan kapasitas kelembagaan ini meliputi usaha penyadaran masyarakat untuk menyusun norma-norma dan aturanaturan yang menyangkut pola perilaku masyarakat yang mana keluaran dari usaha ini adalah terbentuknya lembaga-lembaga berbasis komunitas untuk pembangunan dalam lingkungannya. Peningkatan kapasitas juga meliputi usaha untuk meningkatkan kemampuan manajerial dan berorganisasi masyarakat dalam upaya mewujudkan tata kelembagaan yang lebih partisipatif dan transparan.

Peningkatan kapasitas individu lebih condong pada usaha untuk meningkatkan kemampuan individu-individu masyarakat agar mereka mampu memanfaatkan semua potensi dan kemampuan yang ada pada dirinya untuk dapat dimanfaatkan demi kemajuan masyarakat sekitarnya. Upaya peningkatan kapasitas individu ini meliputi usaha-usaha pembelajaran baik dari ranah pengetahuan, sikap atau penyadaran kritis dan keterampilannya.

Peningkatan kapasitas yang dilakukan di MINU Waru Sidoarjo termasuk pada tingkatan individu yang berusaha meningkatkan kemampuan guru-guru

${ }^{19}$ African Capacity Building Foundation (ACBF), "Capacity Needs Assessment: A Conceptual Framework," ACBF Newsletter Vol. 2, (2001). 
MINU Waru Sidoarjo dalam mengembangkan potensi-potensi dan kemampuan yang telah dimiliki untuk dimanfaatkan demi kemajuan dan peningkatan kualitas pembelajaran di MINU Waru Sidoarjo.

Salah satu faktor kunci dalam pengembangan kapasitas adalah pembelajaran. Pembelajaran terjadi pada tingkat individu, tingkat organisasi dan tingkat masyarakat. Proses pengembangan kapasitas membutuhkan jangka panjang secara berkesinambungan dimana orang-orang belajar untuk lebih capable (lebih mampu melaksanakan pekerjaannya). Karena melalui pembelajaran dapat meningkatkan pengetahuan dan keterampilan, dan mengubah perilaku untuk mencapai sebuah tujuan, yakni memperbaiki kualitas hidup.

Berdasarkan teori pengembangan kapasitas, maka dilakukan diskusi yang berguna untuk menetapkan solusi dari permasalahan yang dihadapi. Dari hasil diskusi tersebut maka diputuskan bersama sebuah solusi dari permasalahan yang dihadapi, yaitu pelaksanaan pelatihan pengembangan media pembelajaran berbasis Ms. Power Pointyang dianggap mampu meningkatkan kapasitas guru MINU Waru Sidoarjo dalam mengembangkan media pembelajaran berbasis teknologi informasi. Pemilihan solusi ini berdasarkan pertimbangan bahwa Ms. Power Point memiliki bentuk yang sangat sederhana serta sangat mudah dan praktis untuk dipergunakan dan dipelajari dalam waktu yang singkat. Namun meskipun sangat sederhana, Ms. Power Point memberikan fasilitas yang cukup memadai untuk membuat media pembelajaran. Justru dengan kesederhanaannya sehingga Ms. Power Point sangat mudah dipelajari. Dengan kreatifitas lebih, Ms. Power Point dapat dioptimalkan dengan baik untuk membuat paket media pembelajaran yang berkualitas.

Ms. Power Point juga memiliki fasilitas yang terdiri dari slide, teks, gambar dan bidang-bidang warna yang dapat dikombinasikan dengan latar belakang yang telah tersedia. fasilitas tersebut dapat dibuat tanpa gerak, atau dibuat dengan gerakan tertentu sesuai keinginan pengguna. Seluruh tampilan dari program ini dapat diatur sesuai keperluan, apakah akan berjalan sendiri sesuai timing yang diinginkan, atau berjalan secara manual, yaitu dengan mengklik tombol mouse, dan sebagainya.

Kemudahan penggunaan Ms. Power Point serta kemudahan dalam mempelajarinya terbukti dari peningkatan kapasitas yang terjadi pada guru MINU Waru II Sidoarjo setelah mendapatkan tindakan pelatihan pada setiap siklus. Walaupun bobot materi yang diberikan pada tiap siklus berbeda dan mengalami peningkatan bobot kesulitannya. Peningkatan kapasitas guru MINU Waru II Sidoarjo dapat dilihat dari perbandingan hasil angket yang diberikan sebelum tindakan pada tiap siklus yang dibandingkan dengan hasil observasi 
selama proses pelatihan berlangsung guna mengukur kemampuan peserta dalam menguasai dan mempraktekkan materi pelatihan yang diajarkan.

Pada siklus 1, diberikan materi pengenalan Ms. Power point, praktek pembuatan teks, grafik dan tabel. Data hasil angket yang diberikan pada sebelum tindakan menunjukkan bahwa rerata kemampuan peserta dalam menyalakan komputer, membuka Ms. Power point baru, membuat presentasi baru, membuka pesentasi lama, menyimpan presentasi yang sudah dibuat, membuat serta mengedit teks dalam presentasi menunjukkan kategori "rendah". sedangkan rerata kemampuan peserta dalam membuat/memasukkan dan mengedit header\&footer, membuat/memasukkan dan mengedit wordart, memasukkan dan mengedit gambar, serta memasukkan dan mengedit clipartmasih tergolong dalam kategori "sangat rendah" karena sebagian besar peserta menyatakan masih belum mampu mengaplikasikannya.

Setelah diberikan tindakan berupa pelatihan dengan materi praktek pembuatan teks, grafik dan tabel, kemudian dilakukan observasi selama proses pelatihan, maka hasil observasi tersebut menunjukkan bahwa kapasitas guru MINU Waru II Sidoarjo dalam menyalakan komputer, membuka program Ms.Power Point, membuat presentasi baru, membuka presentasi lama, menyimpan presentasi yang sudah dibuat, membuat/memasukkan teks dalam presentasi, mengedit teks dalam presentasi serta membuat atau memasukkan wordartberada pada kategori "sangat tinggi". Sedangkan kapasitas dalam membuat/memasukkan header\&footer, mengedit header dan footer, mengedit wordart, memasukkan gambar/ picture, mengedit gambar/picture, memasukkan clipart serta mengedit clipart berada pada kategori "tinggi".

Tabel 2. Perbandingan Kapasitas Guru Pra dan Pasca Tindakan Siklus 1

\begin{tabular}{|c|l|c|c|c|c|}
\hline \multirow{2}{*}{ No. } & \multicolumn{1}{|c|}{ Indikator Kapasitas Guru } & \multicolumn{2}{|c|}{$\begin{array}{c}\text { Pra } \\
\text { Tindakan }\end{array}$} & \multicolumn{2}{|c|}{$\begin{array}{c}\text { Pasca } \\
\text { Tindakan }\end{array}$} \\
\cline { 3 - 6 } & \multicolumn{2}{|c|}{ R } & $\mathrm{K}$ & $\mathrm{R}$ & $\mathrm{K}$ \\
\hline 1. & Menyalakan computer & 2,21 & $\mathrm{R}$ & 3,37 & $\mathrm{ST}$ \\
\hline 2. & Membuka program Ms. Power Point & 1,95 & $\mathrm{R}$ & 3,26 & $\mathrm{ST}$ \\
\hline 3. & Membuat presentasi baru & 1,90 & $\mathrm{R}$ & 3,26 & $\mathrm{ST}$ \\
\hline 4. & Membuka presentasi lama & 1,79 & $\mathrm{R}$ & 3,26 & $\mathrm{ST}$ \\
\hline 5. & $\begin{array}{l}\text { Menyimpan presentasi yang sudah } \\
\text { dibuat }\end{array}$ & 1,95 & $\mathrm{R}$ & 3,26 & $\mathrm{ST}$ \\
\hline 6. & $\begin{array}{l}\text { Membuat/memasukkan teks dalam } \\
\text { presentasi }\end{array}$ & 1,95 & $\mathrm{R}$ & 3,37 & $\mathrm{ST}$ \\
\hline
\end{tabular}




\begin{tabular}{|c|l|c|c|c|c|}
\hline 7. & Mengedit teks dalam presentasi & 1,90 & $\mathrm{R}$ & 3,37 & $\mathrm{ST}$ \\
\hline 8. & $\begin{array}{l}\text { Membuat/memasukkan Header \& } \\
\text { Footer }\end{array}$ & 1,48 & $\mathrm{SR}$ & 3,11 & $\mathrm{~T}$ \\
\hline 9. & Mengedit Header \& Footer & 1,52 & $\mathrm{SR}$ & 3,16 & $\mathrm{~T}$ \\
\hline 10. & Membuat/memasukkan WordArt & 1,57 & $\mathrm{SR}$ & 3,37 & $\mathrm{ST}$ \\
\hline 11. & Mengedit WordArt & 1,48 & SR & 3,11 & $\mathrm{~T}$ \\
\hline 12. & Memasukkan gambar & 1,52 & SR & 3,21 & $\mathrm{~T}$ \\
\hline 13. & Mengedit gambar & 1,63 & SR & 3,21 & $\mathrm{~T}$ \\
\hline 14. & Memasukkan ClipArt & 1,48 & SR & 3,21 & $\mathrm{~T}$ \\
\hline 15. & Mengedit ClipArt & 1,57 & SR & 3,21 & $\mathrm{~T}$ \\
\hline
\end{tabular}

Demikian pula yang terjadi pada siklus 2, pada siklus ini diberikan materi pembuatan grafik, tabel, flowchart, dan animasi berupa slide, gambar, clip art dan smart art. Dari hasil angket yang diberikan sebelum penyajian materi, diketahui bahwa kapasitas guru MINU Waru Sidoarjo berada dalam kategori "sangat rendah" pada setiap indikator kapasitas yang meliputi menambahkan tabel, grafik, teks, gambar, clip art, shape, dan smart art pada Ms. Power point serta memberi animasi pada masing-masing fitur tersebut, dan melakukan croping, serta cara group dan ungroup pada gambar pada Ms. Power point tergolong dalam kategori "sangat rendah".

Setelah diberikan materi dan melakukan praktek, maka diketahui dari hasil observasi bahwa kapasitas guru MINU Waru Sidoarjo dalam menguasai dan mempraktekkan semua indikator kapasitas sebagaimana yang diukur melalui angket meningkat dengan sangat cepat dan berada pada kategori "tinggi".

Tabel 3. Perbandingan Kapasitas Guru Pra dan Pasca Tindakan Siklus 2

\begin{tabular}{|c|l|c|c|c|c|}
\hline \multirow{2}{*}{ No. } & \multirow{2}{*}{ Indikator Kapasitas Guru } & \multicolumn{2}{|c|}{$\begin{array}{c}\text { Pra } \\
\text { Tindakan }\end{array}$} & \multicolumn{2}{c|}{$\begin{array}{c}\text { Pasca } \\
\text { Tindakan }\end{array}$} \\
\cline { 3 - 6 } & & $\mathrm{R}$ & $\mathrm{K}$ & $\mathrm{R}$ & $\mathrm{K}$ \\
\hline 1. & Menambahkan Ms.Power Point baru & 1,74 & $\mathrm{SR}$ & 3,21 & $\mathrm{~T}$ \\
\hline 2. & Menambahkan grafik & 1,63 & SR & 3,10 & $\mathrm{~T}$ \\
\hline 3. & Menambahkan teks & 1,74 & SR & 3,25 & $\mathrm{~T}$ \\
\hline 4. & Menambahkan gambar/ClipArt & 1,74 & SR & 3,21 & $\mathrm{~T}$ \\
\hline 5. & Menambahkan Shapes & 1,63 & SR & 3,10 & $\mathrm{~T}$ \\
\hline 6. & Menambahkan SmartArt & 1,58 & SR & 3,06 & $\mathrm{~T}$ \\
\hline 7. & Memberi animasi pada table & 1,37 & SR & 2,90 & $\mathrm{~T}$ \\
\hline 8. & Memberi animasi pada grafik & 1,32 & SR & 2,79 & $\mathrm{~T}$ \\
\hline
\end{tabular}


Peningkatan Kapasitas Guru

\begin{tabular}{|c|l|c|c|c|c|}
\hline 9. & Memberi animasi pada teks & 1,32 & SR & 2,84 & T \\
\hline 10. & $\begin{array}{l}\text { Memberi animasi } \\
\text { padagambar/ClipArt }\end{array}$ & 1,32 & SR & 2,84 & T \\
\hline 11. & Memberi animasi pada Shape & 1,32 & SR & 2,84 & T \\
\hline 12. & Memberi animasi pada SmartArt & 1,26 & SR & 2,79 & $\mathrm{~T}$ \\
\hline 13. & $\begin{array}{l}\text { Menjalankan animasi pada } \\
\text { teks,gambar/ClipArt Shape,dan } \\
\text { SmartArt }\end{array}$ & 1,42 & SR & 2,95 & $\mathrm{~T}$ \\
\hline 14. & Memotong gambar /Croping & 1,42 & $\mathrm{SR}$ & 2,95 & $\mathrm{~T}$ \\
\hline 15. & $\begin{array}{l}\text { Mengetahui cara Group \&Ungroup } \\
\text { pada gambar/ClipArt pada Ms.Power }\end{array}$ & 1,32 & $\mathrm{SR}$ & 2,84 & \\
\hline
\end{tabular}

Pada siklus 3 peningkatan kapasitas yang terjadi pada guru MINU Waru Sidoarjo dalam menguasai materi yang diajarkan sangat efisien dan memuaskan. Pada siklus ini diberikan materi pembuatan desain media pembelajaran yang meliputi pembuatan templatedancontent. Dari hasil angket yang diberikan pada pra tindakan, diketahui bahwa kapasitas guru MINU Waru Sidoarjo dalam menguasai indikator kapasitas yang meliputi membuat templatebaru dan mengedit serta menyimpannya, membuat shapes dan memberikan animasi pada template, memberi efek 3D pada shapes dalam template kemudian mengeditnya, membuat tombol nafigasi dan mengeditnya serta memberikan animasi berada pada kategori "sangat rendah".

Setelah dilakukan tindakan berupa pemberian materi dan melakukan praktek terhadap masing-masing indikator, menunjukkan peningkatan kapasitas yang sangat memuaskan yang ditunjukkan oleh nilai rerata pada 4 indikator kapasitas yaitu memberikan animasi pada template, memberi efek 3D pada shapes dalam template, mengedit shapes pada template, membuat tombol navigasi baru dalam template berada pada kategori "sangat tinggi". Sedangkan penguasaan terhadap 6 indikator yaitu membuat dan mengedit template, membuat shapes pada template, mengedit tombol navigasi, memberikan animasi pada tombol nafigasi,serta menyimpan template berada pada kategori "tinggi". 
Tabel 4. Perbandingan Kapasitas Guru Pra dan Pasca Tindakan Siklus 3

\begin{tabular}{|c|l|c|c|c|c|}
\hline \multirow{2}{*}{ No. } & \multicolumn{2}{|c|}{ Indikator Kapasitas Guru } & \multicolumn{2}{c|}{$\begin{array}{c}\text { Pra } \\
\text { Tindakan }\end{array}$} & \multicolumn{2}{c|}{$\begin{array}{c}\text { Pasca } \\
\text { Tindakan }\end{array}$} \\
\cline { 3 - 6 } & & $\mathrm{R}$ & $\mathrm{K}$ & $\mathrm{R}$ & $\mathrm{K}$ \\
\hline 1. & Membuat Template & 1,69 & $\mathrm{SR}$ & 3,21 & $\mathrm{~T}$ \\
\hline 2. & Mengedit Template & 1,69 & $\mathrm{SR}$ & 3,21 & $\mathrm{~T}$ \\
\hline 3. & Memberikan animasi pada Template & 1,48 & $\mathrm{SR}$ & 3,32 & $\mathrm{ST}$ \\
\hline 4. & Membuat Shapes pada Template & 1,53 & $\mathrm{SR}$ & 3,16 & $\mathrm{~T}$ \\
\hline 5. & $\begin{array}{l}\text { Memberi efek 3D pada Shapes dalam } \\
\text { Template }\end{array}$ & 1,58 & $\mathrm{SR}$ & 3,26 & $\mathrm{ST}$ \\
\hline 6. & Mengedit Shapes pada Template & 1,58 & SR & 3,32 & $\mathrm{ST}$ \\
\hline 7. & $\begin{array}{l}\text { Membuat Tombol Nafigasi baru } \\
\text { dalam Tamplate }\end{array}$ & 1,63 & SR & 3,26 & $\mathrm{ST}$ \\
\hline 8. & Mengedit Tombol Navigasi & 1,63 & SR & 3,10 & $\mathrm{~T}$ \\
\hline 9. & $\begin{array}{l}\text { Memberi animasi Tombol Nafigasi } \\
\text { dalam Template }\end{array}$ & 1,63 & SR & 3,10 & $\mathrm{~T}$ \\
\hline 10. & Menyimpan Template & 1,69 & SR & 3,16 & $\mathrm{~T}$ \\
\hline
\end{tabular}

Peningkatan yang sangat efisien juga terjadi pada siklus 4. Pada siklus ini diberikan materi desain media pembelajaran yang meliputi pembuatan hiperlink dan slide master. Dari hasil angket yang diberikan pada pra tindakan, diketaui bahwa kapasitas guru MINU Waru Sidoarjo dalam mengetahui fungsi hiperlink dan membuat tomol hiperlink tergolong dalam kategori "rendah". Sedangkan kapasitasnya dalam menghubungkan tombol hiperlink dengan slide, mengetahui fungsi slidemaster, memindahkan template ke slidemaster, membuat slide master, menambah content/isi pada slide master, memberi animasi pada slide master, mengetahui cara setting tombol pada slide master, menjalankan (show) slide master tergolong dalam kategori "sangat rendah".

Setelah dilakukan tindakan berupa pemberian materi dan melakukan praktek terhadap masing-masing indikator, terjadi peningkatan kapasitas guru MINU Waru Sidoarjo dalam menguasai dan mempraktekkan materi yang telah diajarkan sehingga tergolong dalam kategori "tinggi" pada indikator mengetahui fungsi hiperlink, mengetahui fungsi slidemaster, memindahkan template ke slidemaster, membuat slide master, menambah content/isi pada slide master, memberi animasi pada slide master, mengetahui cara setting tombol pada slide master, menjalankan (show) slide master. Sedangkan kapasitas pada indikator membuat tombol hiperlink dan menghubungkan tombol hiperlink dengan slide tergolong dalam kategori "sangat tinggi." 
Tabel 5. Perbandingan Kapasitas Guru Pra dan Pasca Tindakan Siklus 4

\begin{tabular}{|c|l|c|c|c|c|}
\hline \multirow{2}{*}{ No. } & \multicolumn{1}{|c|}{ Indikator Kapasitas Guru } & \multicolumn{2}{c|}{$\begin{array}{c}\text { Pra } \\
\text { Tindakan }\end{array}$} & \multicolumn{2}{c|}{$\begin{array}{c}\text { Pasca } \\
\text { Tindakan }\end{array}$} \\
\cline { 3 - 6 } & & $\mathrm{R}$ & $\mathrm{K}$ & $\mathrm{R}$ & $\mathrm{K}$ \\
\hline 1. & Mengetahui fungsi hyperlink & 1,79 & $\mathrm{R}$ & 3,00 & $\mathrm{~T}$ \\
\hline 2. & Membuat tombol hyperlink & 2,00 & $\mathrm{R}$ & 3,58 & $\mathrm{ST}$ \\
\hline 3. & $\begin{array}{l}\text { Menghubungkan tombol hiperlink dg } \\
\text { slide }\end{array}$ & 1,74 & $\mathrm{SR}$ & 3,58 & $\mathrm{ST}$ \\
\hline 4. & Mengetahui fungsi slidemaster & 1,37 & $\mathrm{SR}$ & 3,00 & $\mathrm{~T}$ \\
\hline 5. & Memindahkan template ke slidemaster & 1,32 & $\mathrm{SR}$ & 3,16 & $\mathrm{~T}$ \\
\hline 6. & Membuat slide master & 1,32 & $\mathrm{SR}$ & 3,21 & $\mathrm{~T}$ \\
\hline 7. & Menambah content/isi pada slide master & 1,42 & $\mathrm{SR}$ & 3,16 & $\mathrm{~T}$ \\
\hline 8. & Memberi animasi pada slide master & 1,53 & $\mathrm{SR}$ & 3,21 & $\mathrm{~T}$ \\
\hline 9. & $\begin{array}{l}\text { Mengetahui cara setting tombol pada } \\
\text { slide master }\end{array}$ & 1,21 & $\mathrm{SR}$ & 3,10 & $\mathrm{~T}$ \\
\hline 10. & Menjalankan (show) slide master & 1,42 & $\mathrm{SR}$ & 3,42 & $\mathrm{ST}$ \\
\hline
\end{tabular}

Peningkatan kapasitas yang terjadi pada guru MINU Waru Sidoarjo dalam menguasai setiap materi yang telah diberikan pada setiap siklus dalam pelatihan ini menjadi bukti dari kemudahan, kepraktisan, efektifitas serta efisiensi yang dimiliki Ms. Power Point untuk dipelajari dan digunakan sebagai media pembelajaran.

Selain itu, peningkatan kapasitas tersebut juga menjadi indikator bahwa pelatihan yang dilakukan dalam meningkatkan kapasitas guru MINU Waru Sidoarjo dalam mengembangkan media pembelajaran berbasis Ms. Power Point adalah berhasil. Hal tersebut dibuktikan dengannilai rerata setiap indikator kapasitas peserta pada tiap siklus yang berada pada kategori "tinggi" dan "sangat tinggi", maka apabila data tersebut di kaitkan dengan kriteria keberhasilan yang ditetapkan dalam penelitian ini yaitu sekurang-kurangnya nilai rerata setiap indikator kapasitas berada pada kategori "tinggi”, maka penelitian ini dikatakan berhasil (lebih jelas lihat gambar 8). Dalam artian, kapasitas guru MINU Waru Sidoarjo dalam mengembangkan media pembelajaran berbasis Ms. Power Point adalah tinggi.

Meningkatnya kapasitas guru MINU Waru Sidoarjo dalam mengembangkan media pembelajaran berbasis Ms. Power Point diharapkan dapat memberikan perubahan yang positif terhadap proses pembelajaran serta karakter dan sosok guru MINU Waru II Sidoarjo. Sebagaimana beberapa manfaat media yang dirumuskan Kemp dan Dayton, antara lain: 1) penyampaian materi 
pelajaran dapat diseragamkan, 2) proses pembelajaran menjadi lebih jelas dan menarik, 3) proses pembelajaran menjadi lebih interaktif, 4) menjadikan waktu belajar lebih efisien, 5) meningkatkan kualitas pembelajaran, 6) memungkinkan proses pembelajaran dilakukan di mana saja dan kapan saja, 7) menumbuhkan sikap positif peserta didik terhadap materi dan proses belajar, 8) Memberikan perubahan positif terhadap guru. ${ }^{20}$

\section{Diagram 1. Peningkatan Kapasitas Guru Minu Waru II Sidoarjo Pada Siklus 1-4}

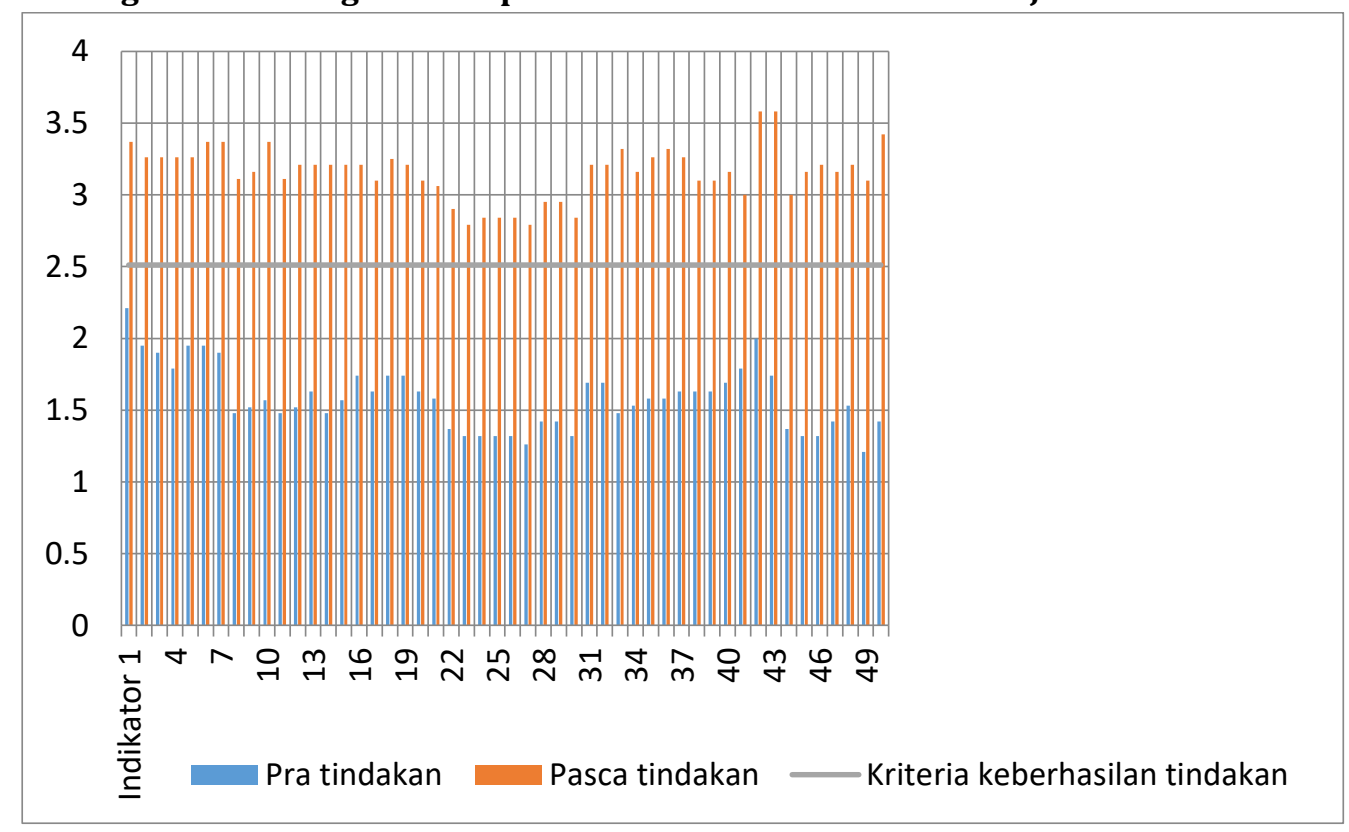

\section{G. Kesimpulan}

Berdasarkan hasil penelitian dan pembahasan yang diuraikan pada bagian sebelumnya, dapat disimpulkan bahwa kapasitas guru MINU Waru Sidoarjo dalam mengembangkan media pembelajaran berbasis teknologi informasi meningkat melalui penerapan pelatihan pengembangan media pembelajaran interaktif berbasis Ms. Power Point dengan memanfaatkan fiturfitur yang tersedia di dalamnya melalui beberapa aktifitas yang meliputi: 1) Pembuatan teks, tabel, grafik, flowchart, input gambar dan clipart; 2) Pembuatan animasi pada slide, gambar, smart art; 3) Desain media pembelajaran yang

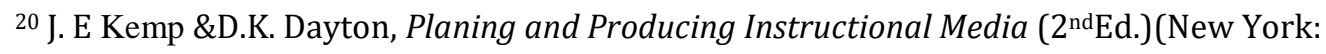

Harper and Row Publish Hers Cambridge, 1980), 3. 
meliputi pembuatan template,content/isi, hyperlink, dan slide master, serta 4) Pembuatan presentasi efektif dengan Ms. Power Point. Hasil penelitian jenis PAR ini positif dan dapat memberdayakan serta mengembangkan kapasitas komunitas guru yang didampingi dalam hal pengembangan media pembelajaran interaktif berbasis teknologi informasi.

\section{H. Referensi}

African Capacity Building Foundation (ACBF), "Capacity Needs Assessment: A Conceptual Framework," ACBF Newsletter Vol. 2, (2001).

Anas,Muhammad."Pemanfaatan TIK dalam Pembelajaran di ProvinsiSulawesi Utara,"Jurnal Simposium Pendidikan, Vol.4.2, 2009.

Anelli, Milen. Pegangan Dasar Pengembangan Kapasitas, Terjemahan (Yogyakarta: Pondok Pustaka Jogja, 2004).

Arief am, http://abiavisha.blogspot.com/2014/03/bahan-ajarku-mediapembelajaran.html diakses pada 05 Januari 2015.

B.M., Miles\& Huberman, D., Effective Teaching: Evidence \& Practice, $2^{\text {nd }}$ (London: Sage Publication, 1984).

D. J., Greenwood, Whyte, W. F., \& Harkavy, I., "Participatory Action Research as a Process and as a Goal,"Human Relations, 46 (2), (1993).

Green, et.al, "Appendix C: Guidelines for Participatory Research in Health Promotion," in Minkler, Meredith and Nina Wallerstein, ed. CommunityBased Participatory Research for Health (San Francisco, CA: Jossey-Bass Inc.), 2003.

J. E., Kemp \&D.K. Dayton, Planing and Producing Instructional Media (2 ${ }^{\text {nd }}$ Ed.) (New York: Harper and Row Publish Hers Cambridge, 1980).

J.M., Chevalier, and Buckles, D.J., Participatory Action Research: Theory and Methods for Engaged Inquiry(London: Routledge, 2013).

Mardapi,Djemari.Teknik penyusunan Instrumen Tes dan Non Tes (Yogyakarta: Rosda, 2008).

P., Reason, and Bradbury, H., 'Introduction', in P. Reason and H. Bradbury, ed.The

Sage Handbook of Action Research: Participative Inquiry and Practice (CA: Sage, 2008).

Sadiman,Arief, dkk., Media Pendidikan (Jakarta: Pustekkom Diknas \& PT. Raja Grafindo Perkasa).

Suprapto, "Peningkatan Kualitas Pendidikan MelaluiMedia Pembelajaran Menggunakan Teknologi Informasi di Sekolah,"Jurnal Ekonomi dan Pendidikan, Vol.3.1, 2006. 
Hanik Yuni Alfiyah, Asma' Naily Fauziyah, Masfufah

Suyanto, Pedoman Pelaksanaan Penelitian Tindakan Kelas (PTK) (Yogyakarta: DIKBUD, 1997).

Tiyuk Fu'adah (Guru Komputer), Wawancara pada tanggal 14 Januari 2015.

Wawancara terbuka dalam FGD dengan semua guru MINU Waru II Sidoarjo pada tanggal 8 januari 2015.

Wesley A., Fryer."Strategy for effective Elementary Technology Integration", dalamhttp://www.wtvi.com/teks/integrate/tcea2001/powerpointoutlin e, diakses pada 05 Januari 2015.

www.wikipedia.com, diakses pada tanggal 11 Mei 2014.

Zawidah Abdullah (Kepala Sekolah), Wawancara pada tanggal 8 Januari 2015. 